\title{
EFFECT OF ORAL ADMINISTRATION OF ETHANOLIC EXTRACT OF TAPINANTHUS GLOBIFERUSA. RICH ON LIVER FUNCTION IN RATS
}

\author{
${ }^{1}$ Abdullahi, M.H*., ${ }^{2}$ Danjuma, N.M., ${ }^{1}$ Yaro, A.H. and ${ }^{3}$ Abubakar, S. \\ ${ }^{1}$ Department of Pharmacology, Bayero University, Kano \\ ${ }^{2}$ Department of Pharmacology and Therapeutics, Ahmadu Bello University, Zaria \\ ${ }^{3}$ Department of Histopathology, Aminu Kano Teaching Hospital, Kano \\ *Corresponding author: am.huguma@yahoo.com;Tel: +234-806-554-1850
}

\begin{abstract}
The effects of ethanol extract of Tapinanthus globiferus in the liver of rats were evaluated on serum levels of alanine aminotransferase (ALT), aspartate aminotransferase (AST), alkaline phosphatase $(A L P)$, total protein (TP), total bilirubin (TB) and conjugated bilirubin (CB) while histological analysis was evaluated on section of liver after 28 days of oral administration. The oral $L D_{50}$ of the extract in rats was found to be greater than $5,000 \mathrm{mg} / \mathrm{kg}$ body weight. The biochemical analysis revealed no significant changes ( $p>0.05$ ) in serum levels of AST, ALT, ALP and TP at all doses treated (87.5, 175 and $350 \mathrm{mg} / \mathrm{kg})$ but there was significant $(p<0.05)$ evaluation of serum TB at higher dose and significant ( $p<0.05)$ dose dependent increase in $C B$ when compared with control. The photomicrograph of transverse section of the liver treated with doses of 175 and $350 \mathrm{mg} / \mathrm{kg}$ showed areas of fibrosis at 100 magnifications while no effect was observed at $87.5 \mathrm{mg} / \mathrm{kg}$ body weight. This work revealed that, Tapinanthus globiferus extract has no toxic effect on the liver of rats after short and low dose administration but can cause sign of liver damage at higher dose.
\end{abstract}

Key words: Tapinanthus globiferus, Biochemical, Ethanol, Histological, Photomicrograph

\section{INTRODUCTION}

The extent to which an organ is susceptible to toxicity depends on the nature of organ or exposure of the organ to toxicant. For example the kidneys and liver are more highly vascularised making them more susceptible to toxicity than the bone tissues. The toxicity of plants is caused by the presence of certain compounds such as cyanogenic glycosides and lectins (Daisy et al., 2009). Many food plants possess toxic compounds unless processed, or are toxic at certain stages of their life. Several plant extracts have been examined for use in a wide variety of liver disorders, while others have been reported to cause injury to the liver (Atawodi et al., 2011). Liver is the main organ involved in drug biotransformation (Dadzeahah, 2012). The measurement of serum alanine aminotransferase (ALT), aspartate aminotransferase (AST), alkaline phosphatase (ALP), total protein (TP) and total bilirubin (TB) levels serve as a means for the indirect assessment of condition of liver. Increases in the levels of ALT, AST, ALP, TP and TB in the serum are associated with liver damage or toxicity by drugs or any other hepatotoxic agents (Daisy et al., 2009). Hence, the amount of ALT, AST, ALP, TP and TB in the blood is directly related to the extent of the liver damage.

Tapinanthus globiferus is a species of mistletoe growing on other plant host, it is locally known as mistletoe (English), Kauchin kadanya (Hausa), Eme-emi afomo (Yoruba), and Osisi/Okwuma osa (Igbo) in Nigeria and belongs to the family of Loranthaceae (Burkill, 2000). Mistletoe is a common name for various parasitic plants belonging to mostly loranthaceae family. Tapinanthus globiferus is a semi-parasitic plant that mostly grows or attaches on the branches of a large number of tree species such as Vitellaria paradoxa, Kola, Citrus, Combretum, Acacia, Aloe and
Terminalia as host tree to obtain their nutrients (Waterberg et al., 1989). It is semi-parasitic because most mistletoe photosynthesizes, although they may obtain up to $60 \%$ of their carbohydrates as well as the supply of water and minerals from the host (Watson, 2001). Mistletoes are used in traditional medicine in the treatment of inflammations, malaria, bacterial infections, ulcer, headaches, diabetes mellitus, stroke, stomach problems, as well as convulsions (Osadele and Ukwueze, 2004). Most species of mistletoe have evolved to mimic the foliage of their host tree and also their efficacy defending on the host tree (Watson, 2001). Several research on many mistletoe were conducted and were reported to possess a number of therapeutic uses for managing a wide range of diseases such as diabetes mellitus, stroke, stomach problems, heart palpitations, high blood pressure and breathing difficulties (Osadele and Ukwueze, 2004: Karakas et al., 2008; Bassey, 2012). In Nigeria, the Hausa and Fulani tribes of Northern Nigeria use T. globiferus in the treatment of cancers and inflammations (Abubakar et al., 2007). Tapinanthus globiferus is one of the mistletoe used in traditional medicine in the management of epilepsy, headache, diabetes mellitus and schizophrenia (personal communication). There is little or no scientific backing on the safety of the plant as used traditionally. Hence there is need for study the toxicity of $T$. globiferus plant. The objective of this study is to investigate the toxic effects of ethanolic extract of Tapinanthus globiferus on the functional and structural integrity of the liver in rats.

\section{MATERIALS AND METHODS}

Plant collection and Identification: Fresh Tapinanthus globiferus (mistletoe) of Vitellaria paradoxa tree was collected from Huguma village of Takai L.G.A, Kano State in the month of October, 2014. 
The plant was identified and authenticated in the herbarium of the Department of Biological Sciences, Ahmadu Bello University Zaria, Nigeria by comparing with voucher specimen number 1052.

Plant extraction: The mistletoe was air dried under shade at room temperature $\left(27^{\circ} \mathrm{C}\right)$ for 28 days and then grounded into a fine powder using pestle and mortar. Powdered material $(600 \mathrm{~g})$ was used for the extraction in aqueous - ethanol (aqueous 25\%: ethanol $75 \%$ ) and the extraction was carried out using Soxhlet extractor. The extract was concentrated on water bath at temperature of $60^{\circ} \mathrm{C}$.

Experimental Animals: Twenty four rats (weighing 150 - $180 \mathrm{~g}$ ) were obtained from animal House of the Department of Pharmacology, Bayero University Kano. Animals were kept in a well-ventilated room, fed with a pelletized grower mash (Vital feeds, plc. Jos) and water provided ad-libitum.

Animal Grouping: Twenty four (24) Wister albino rats of either sex weighing between 150 to $180 \mathrm{~g}$ were used for this study. Rats were randomly divided into four (4) groups of six (6) rats each. The Group I served as control and was treated with normal saline $(1 \mathrm{ml} / \mathrm{kg}$ body weight), while Group II, Group III and Group IV were treated with $87.5,175$ and $350 \mathrm{mg} / \mathrm{kg}$ of the ethanol extract of $T$. globiferus orally respectively on daily basis for twenty eight (28) days, after which rats were sacrificed on the $28^{\text {th }}$ day.

Acute toxicity study: The determination of oral median lethal dose $\left(L D_{50}\right)$ of the ethanol extract of $T$. globiferus was conducted using the method of Lorke (1983).

Biochemical study: Blood was collected by cardiac puncture from rats for test of liver function indices. Serum alkaline phosphatase (ALP) was estimated using method of Rec (1987) while those of aspartate aminotransferase (AST) and alanine aminotransferase (ALT) were estimated using colorimetric method of Reitman and Frankel (1957). Total bilirubin (TB) and conjugated bilirubin (CB) was estimated using the method of Jendrassik and Grof (1938) while total protein (TP) by using method of Tietz (1995).
Histopathological study: Method of Auwioro (2010) was used for histopathological study. Rats were sacrificed at the end of the treatment period following chloroform anaesthesia. The rat liver were harvested and preserved in $10 \%$ formalin solution. Sections of the liver were fixed with $10 \%$ normal saline, dehydrated with ascending grade of alcohol, cleared with toluene, infix-treated with molten paraffin wax and embedded with paraffin wax. The microtome sections of the tissues were stained with haematoxylin and eosin staining technique. Slides were prepared and observed using a standard electronic microscope.

Statistical analysis: Results of ALT, AST, ALP, TP, TB and $\mathrm{CB}$ were expressed as Mean \pm Standard error of mean (Mean \pm SEM) and the differences between means were considered significant when $p \leq 0.05$. Data were analysed using one - way analysis of variance (ANOVA) followed by Bonferroni, Dunnet's, and Tukey HSD post - hoc tests.

\section{RESULTS}

Acute toxicity evaluation: The median lethal dose $\left(L D_{50}\right)$ of ethanol extract of $T$. globiferus after oral administration was found to be greater than 5,000 $\mathrm{mg} / \mathrm{kg}$ in rats.

Biochemical analysis: Twenty eight days oral treatment of $T$. globiferus extract at all doses (87.5, 175 and $350 \mathrm{mg} / \mathrm{kg}$ ) showed no significant effect on serum levels of AST, ALT, ALP and TP. However, a significant change in TB and CB $(p<0.05)$ was observed at doses of 87.5 and $350 \mathrm{mg} / \mathrm{kg}$ body weight. The extract also produced a significant $(p<0.05)$ and dose dependent increase in serum level of CB when compared with control (Table 1).

Histopathological analysis: The histological examination of the rats liver section treated with ethanol extract of T. globiferus at doses of 175 and 350 $\mathrm{mg} / \mathrm{kg}$ showed areas of fibrosis (Fig. 3 and 4). However, the liver section of rats that received dose of $1 \mathrm{ml} / \mathrm{kg}$ normal saline and $87.5 \mathrm{mg} / \mathrm{kg}$ extract showed no remarkable histological changes (Fig. 1 and 2).

Table 1: Effect of ethanolic extract of Tapinanthus globiferus on liver biomarkers

\begin{tabular}{|c|c|c|c|c|c|c|c|}
\hline Group & $\begin{array}{c}\text { Treatment } \\
\text { (mg/kg) }\end{array}$ & $\begin{array}{c}\text { AST } \\
(U / L)\end{array}$ & $\begin{array}{l}\text { ALT } \\
(U / L)\end{array}$ & $\begin{array}{l}\text { ALP } \\
(U / L)\end{array}$ & $\begin{array}{c}\text { TB } \\
(\mu \mathrm{mol} / \mathrm{L})\end{array}$ & $\begin{array}{c}\text { CB } \\
(\mu \mathrm{mol} / \mathrm{L})\end{array}$ & $\begin{array}{l}\mathrm{TP} \\
(\mathrm{g} / \mathrm{dl})\end{array}$ \\
\hline \multicolumn{2}{|c|}{$\begin{array}{c}\text { I Normal saline } \\
(1 \mathrm{ml} / \mathrm{kg})\end{array}$} & $8.80 \pm 3.79$ & $11.60 \pm 3.20$ & $50.00 \pm 9.00$ & $27.79 \pm 0.90$ & $17.52 \pm 0.08$ & $6.76 \pm 0.17$ \\
\hline II & 87.5 & $10.00 \pm 1.90$ & $12.60 \pm 2.11$ & $59.60 \pm 7.61$ & $25.79 \pm 0.40^{a}$ & $14.82 \pm 0.11^{\mathrm{a}}$ & $7.04 \pm 0.16$ \\
\hline III & 175 & $10.40 \pm 1.72$ & $16.00 \pm 3.44$ & $54.80 \pm 8.41$ & $27.16 \pm 0.30$ & $15.77 \pm 0.14^{\mathrm{a}}$ & $7.04 \pm 0.19$ \\
\hline IV & 350 & $12.50 \pm 2.26$ & $21.00 \pm 4.99$ & $47.67 \pm 8.98$ & $35.21 \pm 0.29^{a}$ & $16.93 \pm 0.11^{a}$ & $6.67 \pm 0.20$ \\
\hline
\end{tabular}

${ }^{a} \mathrm{P}<0.05$, one way ANOVA followed by Bonferroni, Dunnet's and Tukey HSD (Post-hoc test), Mean \pm SEM, $\mathrm{n}=6$ 


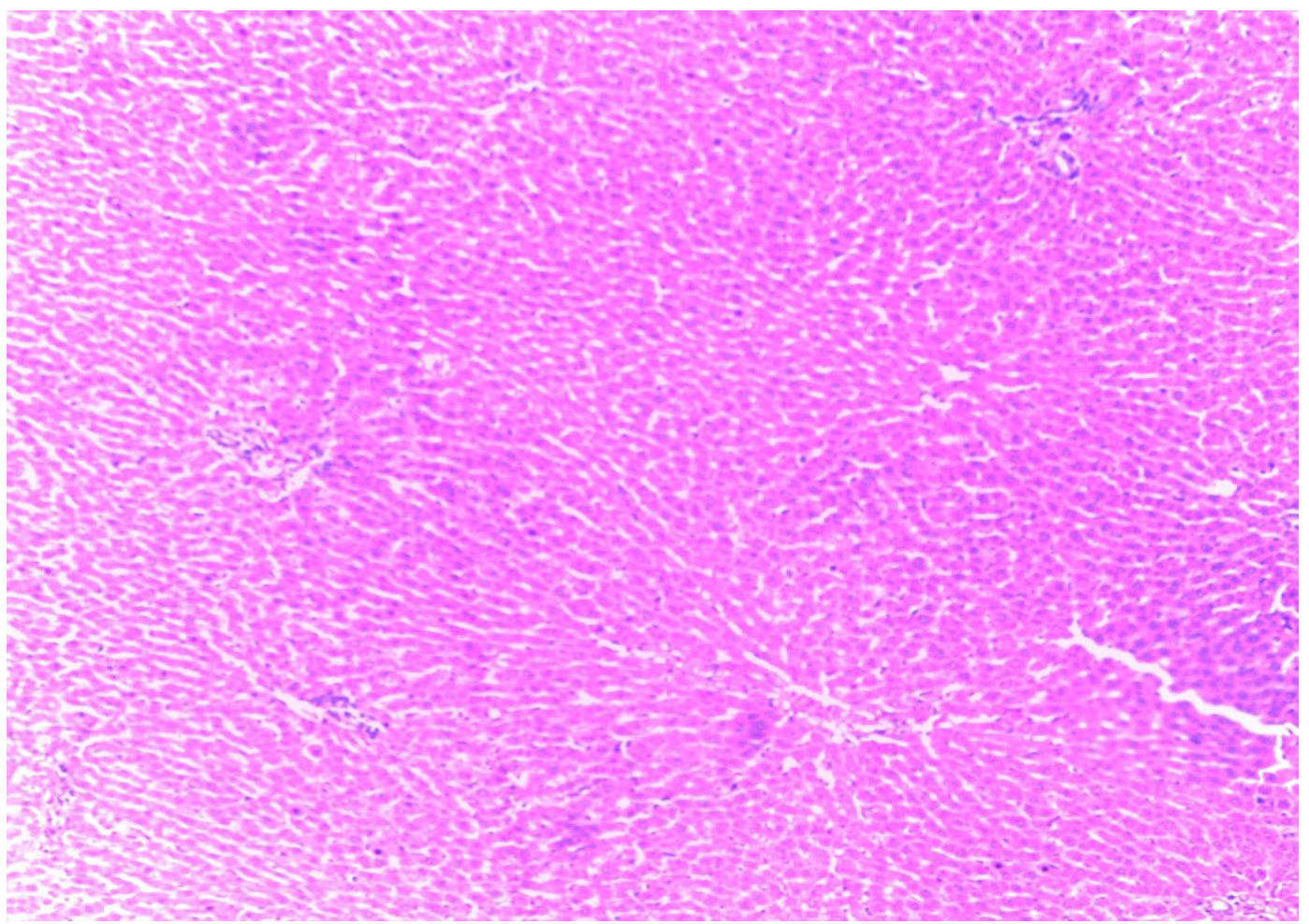

Fig. 1: Photomicrograph of transverse section of the liver of rat that received a dose of $1 \mathrm{ml} / \mathrm{kg}$ normal saline, Section shows no significant pathology (H and E stain x100).

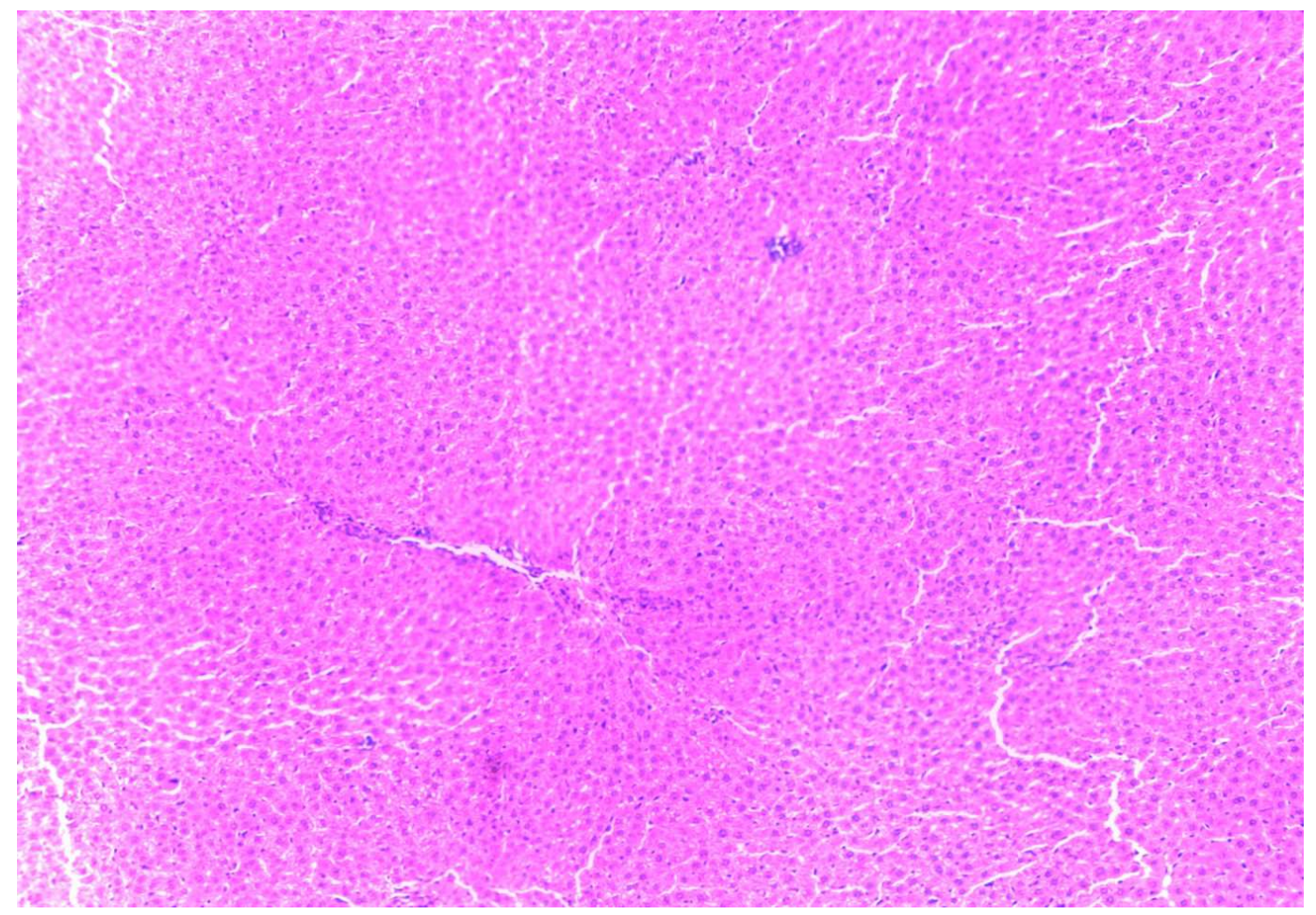

Fig. 2: Photomicrograph of transverse section of the liver of rat that received a dose of 87.5 $\mathrm{mg} / \mathrm{kg}$ Extract, Section shows no significant pathology (H and E stain x100). 


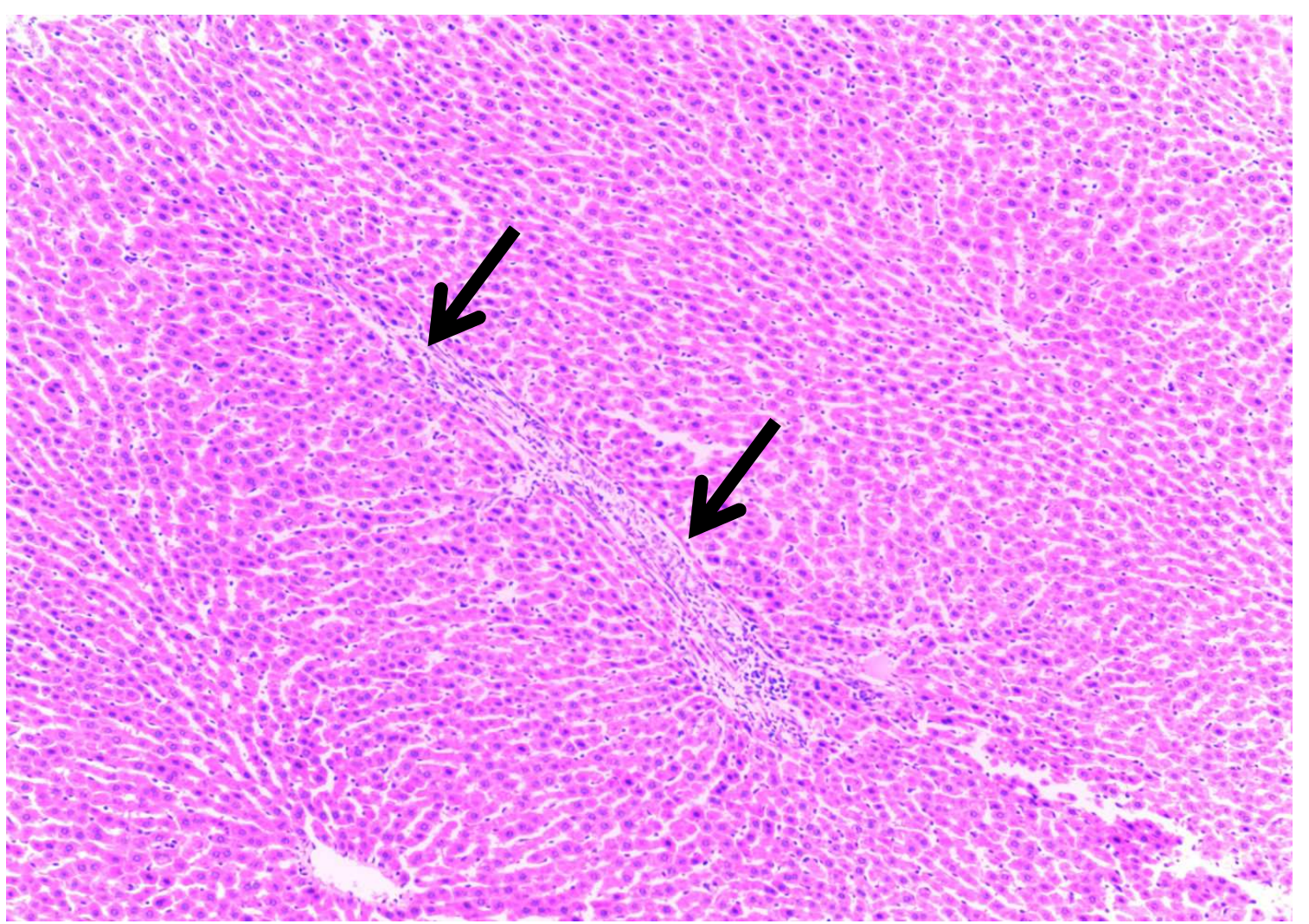

Fig. 3: Photomicrograph of transverse section of the liver of rat that received a dose of $\mathbf{1 7 5}$ $\mathrm{mg} / \mathrm{kg}$ Extract, Section shows area of fibrosis (H and $\mathrm{E}$ stain $\mathbf{x 1 0 0})$.

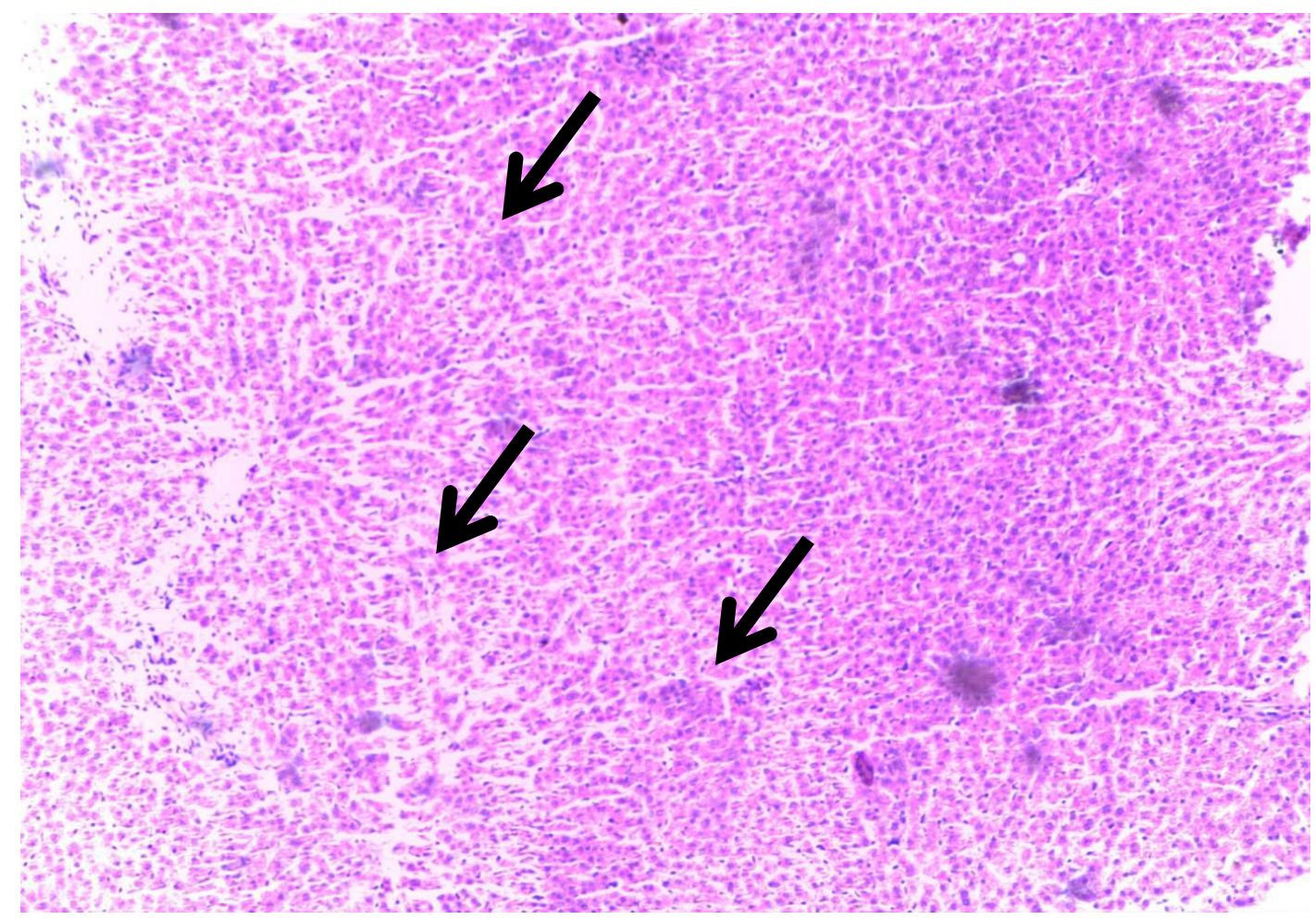

Fig. 4: Photomicrograph of transverse section of the liver of rat that received a dose of $350 \mathrm{mg} / \mathrm{kg}$ Extract, Section shows area of fibrosis (H and E stain x100). 


\section{DISCUSSIONS}

The effects of ethanol extract of Tapinanthus globiferus on biochemical and histological of rat liver were evaluated in this research. The $L D_{50}$ of the extract after oral administration was found to be greater than 5,000 $\mathrm{mg} / \mathrm{kg}$ in rats. This showed that, the extract was practically non-toxic via oral administration in rats. According to the scale of Lorke (1983), any compound with $L D_{50}$ greater than $5,000 \mathrm{mg} / \mathrm{kg}$ should be considered practically non-toxic. The serum levels of ALT, AST, ALP and TP did not show any significant changes when compared with control. Higher ALT and AST activities are indicative parameters of liver damage or disorders. However, ALT is more specific to liver and thus a better parameter for detecting liver injury as AST is also associated with diseases of other organs such as heart and muscle (Ezeji et al., 2014). ALP is present mostly in cells lining the biliary duct of the liver and is used to diagnose obstruction to the biliary system and its elevation in the blood indicates cholesteric diseases such as gallstone or tumour blocking the bile duct (Ezeji et al., 2014). An increase or decrease in serum total protein is not common. Research has shown that an increase in serum TP is usually due to increase in globulin production, chronic infections or liver disease while decrease is associated with high tissue demands for protein, this is due to serious liver damage or liver disease associated with a reduction in proteins synthesis, loss of protein from the body in urine and low protein intake (Kuete et al., 2010). Hence, liver damage or disease may result in reduction of proteins synthesis. The observed increased in serum TB level at higher dose might not be as a result of liver damage because there was an increase in the level of CB at the same dose. The level of CB in the

\section{REFERENCES}

Abubakar, M.S., Musa, A.M., Ahmed, A. and Hussaini, I.M. (2007): The Perception and Practice of Traditional Medicine in the treatment of Cancers and Inflammations by the Hausa and Fulani Tribe of Northern Nigeria. Journal of Ethnopharmacol, 3(3): 625-629.

Arthur, C.G. and John, E.H. (1986): Metabolism and Temperative Regulation. In: Medical Physiology (9th ed). W. B. Sanders Company, London. Pp. 886 - 888.

Atawodi, S. E., Ene, A. C., and Ameh, D. A. (2011): Hepatotoxic effects of chloroform extract of Artemisia macivera Linn in rats following intraperitoneal administration of different subchronic doses. Hum Exp Toxicol, 30(1): 25-33.

Auwioro, O.G., (2010): Histochemistry and Tissue pathology Principles and Techniques $2^{\text {nd }}$ edition. University press Delta State University, Abraka Nigeria, Pp. 561 - 568.

Bassey, M.E. (2012): Phytochemical Investigations of Tapinanthus globiferus (Loranthaceae) from two Hosts and Taxonomic implication. International Journal of Chemical, Environment and Pharmaceutical Research, 3(2): $174-177$. blood depends on TB, because the biotransformation of TB increases the level of blood CB. Bilirubin is a metabolic product formed from the breakdown of erythrocytes and increase in serum TB could be due to damage of the liver cells or hepatic diseases like jaundice and obstruction of the duct (Arthur and John, 1986). However, increased bilirubin levels reflect the depth of jaundice. The histological observation of the rats liver section treated with normal saline and low dose of extract showed no pathological effect but there was sign of toxicity in rats that received higher doses, this is may be due to the long term extract administration or use of large doses which have the potential to alter the normal appearance of the liver. The toxicity of this extract at higher dose might be related to increase in the concentration of toxic chemical constituents. Tapinanthus globiferus have been reported to contained alkaloids, flavonoids, saponins, tannins and cardiac glycosides (Bassey, 2012). However, the presence of these constituents in T. globiferus extract at higher concentration may lead to its toxicity at higher dose.

\section{CONCLUSION}

The ethanol extract of Tapinanthus globiferus has no toxic effect on the functional and structural integrity of the rat liver after short and low dose daily treatment. Hence, low dose of $T$. globiferus could be considered relatively safe for use in traditional medicine and suggests that prolonged use of higher dose must be avoided so as to minimize the risk of liver damage.

\section{ACKNOWLEDGMENT}

We acknowledge all those who in one way or the other, contributed towards the success of this study. We do appreciate your hard work, dedication, commitment and discipline.

Burkill, H.M. (2000): Useful Plants of West Tropical Africa. Vol.5 $2^{\text {nd }}$ edition Royal Botanic Gardens, Kew England, Pp. 548-560.

Dadzeasah, P.E.A. (2012): Safety evaluation and hepatoprotective activity of the aqueous stem bark extract of Spathodea campanulata. PhD thesis. Department of Pharmacology, University of Science and Technology, Kumasi, Pp $22-28$.

Daisy, P., Eliza, J. and Farook, K.A. (2009): A novel dihydroxy gymnemic triacetate isolated from Gymnema sylvestre possessing normoglycemic and hypolipidemic activity on STZ induced diabetic rats. Journal of ethnopharmacology, 126: 339 - 344.

Ezeji, M.I., Anaga, A.O. and Asuzu, I.U. (2014): Acute and sub-chronic toxicity profile of methanol leaf extract of Gouania longipetala in rats. Journal of ethnopharmacology, 151: 1155 1164.

Jendrassik, L. and Grof, P. (1938): Colorimetric method for determination of serum bilirubin. Biochmistry $Z, 297: 81$.

Karakas, A., Serin, E., Gunduz, B. and Ucer, A.T. (2008): The Effects of Mistletoe (Viscum album L. Subsp. album) extract on Isolated Intestinal Contractions. Turk. Journal of Biol. 32:237-242. 
Kuete, V., Manfouo, R.N. and Beng, V.P. (2010): Toxicological evaluation of the hydroethanol extract of Tabernaemontana crassa (Apocynaceae) stem bark. Journal of Ethnopharmacology. 130: 470 - 476.

Lorke, D. (1983): A new Approach to Practical Acute Toxicity Testing. Archives of Toxicology Journal, 54: 275 -287.

Osadele, P.O. and Ukwueze, S.E. (2004): A comparative study of the phytochemical and antimicrobial properties of the Eastern Nigerian species of African mistletoe (Loranthus micranthus) sourced out from different host trees. Journal of Biol. Biotechnol, 2(1):18-23.

Rec, G.S.C. (1987): Colorimetric method for serum alkaline phosphatase determination. Journal of Clinical Biochemistry, 10(2): 182.
Reitman, S. and Frankel, S. (1957): A colorimetric method for the determination of serum glutamic oxaloacetate and glutamic pyruvic transaminase. American Journal of Clinical Pathology, 28:56.

Tietz, N.W. (1995): Clinical Guide to laboratory Tests. Third Edition W.B. Saunders Company, P.A. Pp $518-519$.

Waterberg, F., Craven, P. and Marais, L. (1989): Common world flowers of the Okavango Delta. Gamsberg Publishers, Shellfield guide series II.

Watson M. David (2001): Mistletoe In: A keystone Resource in Forest and Woodlands Worldwide, Bathurst New South wales, Australia, Ann. Rev. Ecol. Syst. 32:223. 